\title{
EFFECTS OF CAJUPUT AND CITRONELLA GRASS AS HOST PLANTS ON SANDALWOOD GROWTH
}

\author{
JONI TEFNAI $^{1 *}$, IRDIKA MANSUR ${ }^{2)}$ AND NURHENI WIJAYANTO ${ }^{2)}$ \\ 1) Study Program of Master Degree in Tropical Silviculture, Forestry Faculty IPB, Dramaga Campus, Bogor, 16680, \\ Indonesia \\ 2) Department of Tropical Silviculture, Faculty of Forestry IPB, Dramaga Campus, Bogor, 16680, Indonesia
}

*Email: jonitefnai12@gmail.com

Accepted August 20, 2020 / Approved August 09, 2021

\begin{abstract}
Sandalwood (S. album) is native species in eastern Indonesia, especially East Nusa Tenggara (NTT). Its species can produce essential oils and have been known to foreign countries. However, the community's interest in planting sandalwood is low due to a lack of knowledge regarding cultivation techniques and a long harvest period. The purpose of this study was to assess the growth of sandalwood (S. album) with cajuput (M. cajuputi) citronella grass (C. nardus) as the host plant. The research was conducted in Fatunisuan Village, Miomaffo Barat Subdistrict, TTU Regency using a completely randomized design (RAL) of 4 treatments and 3 replications, namely sandalwood without a host (K), sandalwood with cajuput host (CKP), sandalwood with citronella grass as the host plant (CSW), and sandalwood with cajuput and citronella grass as host plants (CKPSW). Data analysis used variance at $95 \%$ confidence level. Analysis of variance, which showed that the treatment had a significant effect, was further tested using the Duncan Multiple Range Test (DMRT) at the 5\% level. The results showed that the mixed system using two types of hosts, namely lemon grass, cajuput or both, significantly increased the growth of sandalwood in the field. The CKPSW treatment gave the highest percentage increase in sandalwood growth compared to other treatments.
\end{abstract}

Key words: cajuput host, citronella grass host, RAL, sandalwood

\section{INTRODUCTION}

Sandalwood (S. album) is a native species of eastern Indonesia, especially in East Nusa Tenggara (NTT). This plant produces essential oils which have already well known to foreign countries due to its distinctive aroma and therefore, it has high economic value. With this economic value, sandalwood has contributed to the Regional Original Income (PAD) of NTT Province. In 1989-1994, its wood production reached $245 \mathrm{~kg}$ (Banoet, 2001). According to Haryjanto (2007), sandalwood population is threatened with a high risk of extinction in the very near future because it is vulnerable to a ruthless exploitation leading to the decrease in area and habitat quality. Currently, sandalwood population in NTT is categorized as endangered flora (IUCN, 2007).

Sandalwood restoration in NTT is stated in the Master Plan and Action Plan for Sandalwood Development in NTT Province since 2010-2030, by planting 470 sandalwood seedlings within a period of four years (Balitbang Forestry Kupang, 2009). The NTT Provincial Government has planned to develop a sandalwood forest with an area of 500 ha on state-owned land (East Nusa Tenggara Provincial Forestry Service, 2009). Another effort that can be made to support the development of sandalwood cultivation is utilizing many types of host plants.

Host plant is one of the factors that having a role to affect the success of sandalwood cultivation (Putri and Herawan, 2008). There are many types of host plants that have been used to support the growth of sandalwood in the seedbed and in the field. However, public interest in planting sandalwood is still low. The community has not been familiar with sandalwood cultivation techniques, so it is difficult for farmers to plant sandalwood.

Rahayu et al. (2002) stated that sandalwood cultivation often find difficulties to grow, even from its initial seedling development Citronella grass (C. nardus) and cajuput oil (M. cajuputi) are types of plant that has economic value. Citronella grass is herb that can grow in dry soil, so it is suitable as a host for sandalwood (Fitriani et al., 2013). Cajuput is found in NTT and can grow in dry land without requiring intensive care (Widianto and Siarudin 2014).

Sandalwood is a hemiparasite plant that is why it depends on host plants to support its growth. Besides, it has haustorium functioned as a nutrient distributor and a bridge that partially connects with its host plant (Weber, 1990). The host plants that are currently under study have low economic value or even do not have economic value such as purslane which does not contribute to the community, so that it has not been able to increase public interest in planting sandalwood.

Citronella grass has been proven to be used as a host plant for sandalwood (Pareira et al., 2018), while cajuput has never been reported to be used as a sandalwood host plant. Cajuput is used as a host plant for sandalwood because it is quite productive so that it can help the community's economy. The objective of this research is to study the growth of sandalwood (S. album) with cajuput (M. cajuputi) and citronella grass $(C$. nardus) as host plants. This research is expected to be 
able to provide information and understanding about the utilization of cajuput and citronella grass as host plants to improve the growth of sandalwood seedlings.

\section{RESEARCH METHOD}

This research was conducted in Fatunisuan Village, West Miomaffo District, North Central Timor (TTU) Regency, East Nusa Tenggara Province (NTT) on July 2018-July 2019 (Figure 1). The research location was at 600-1000 $\mathrm{m}$ above sea level, with the average rainfall of 600-1600 $\mathrm{mm} /$ year, and the average and temperature ranges from $10-35^{\circ} \mathrm{C}$. The maximum temperature during the research was $29.4-33.1{ }^{\circ} \mathrm{C}$.

Materials used in this research were wood ash, sandalwood seeds from TTU Regency, and citronella host plant with a variant of Mahapengiri from the Research Institute for Tropical Spices and Medicinal Plants (Balitro) Lembang, West Bandung Regency. Cajuput seeds were collected from Madiun. Media used in this research consisted of sand, manure, and soil. The soil was taken from the topsoil of a garden in Fatunisuan
Village, West Miomaffo District, TTU Regency, NTT Province.

The tools used in this research included: plastic bags, polybags, shovels, hoes, crowbars, rulers, machetes, analytical scales, hand spryer, paranet, camera, scissors, caliper, wooden pegs with a diameter of $20 \mathrm{~mm}$ and $50 \mathrm{~cm}$ long, and stationery.

\section{Sandalwood (S. album) Seeds Preparation}

Sandalwood seeds were obtained from sandalwood trees taken from Fatunisuan Village, West Miomaffo District, TTU Regency. Sandalwood seeds taken from the tree were $1 \mathrm{~kg}$. Furthermore, seed selection was carried out by selecting seeds that were pale and black, but some of the seeds could not be used in seedbed. To produce good quality seeds, the researcher selected good seed sources, harvested or collected the right seeds, conducted drying, sorting, storing and seeding properly. Next, the seeds were soaked in the water for 24 hours in order to break the dormancy and drying. After that, the sandalwood seeds were put in a plastic bag and mixed with ash until the seeds germinated (3 weeks after treatment).

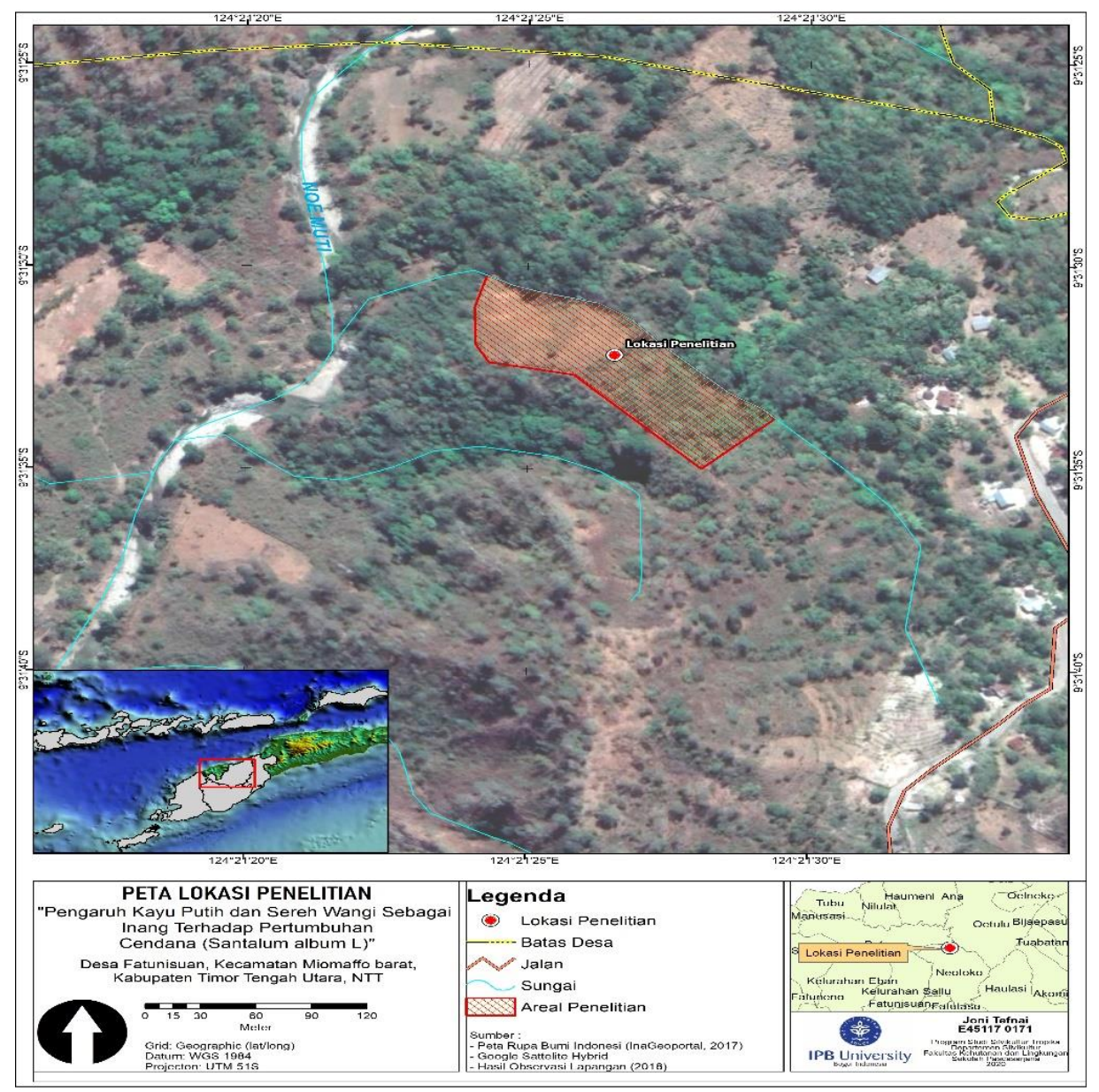

Figure 1 Research Location Map 
500 sandalwood seeds were used in this research. The number of seeds that had germinated for 3 weeks was 124 seeds of the total sandalwood seeds. Furthermore, the media used were a mixture of sand, topsoil and manure with a ratio of 4:1:1 (Surata 2012). The sandalwood seeds that were 1 month old $(4.2 \mathrm{~cm}$ high) were then moved to polybags and planted directly with the seeds of plants to be used as sandalwood plants, including chili ( $C$. annum) and purslane (Alternanthera $s p$ ) host plants. These host plants were used as secondary hosts for sandalwood before they were moved to the field. The sandalwood seeds were planted directly with the host plants, such as chili (C. annum) and purslane (Alternanthera $s p$ ) in 3 seeds/polybags with a depth of $0.5 \mathrm{~cm}$. Chili seeds used as host plants were propagated by performing seed germination. Meanwhile, for purslane, it was performed by stem cuttings. The breeding included watering once a day (morning) and weeding out weed growing around sandalwood seedlings.

Plant spacing is one of the most important treatment factors in supporting the success of sandalwood growth. Therefore, this research considered the results of previous studies conducted by other researchers. According to Wawo (2009), the spacing implemented between plants in polybags is $5 \mathrm{~cm}$. According to Surata (2012), the right polybag size as a planting medium is 15 $\mathrm{x} 25 \mathrm{~cm}$ and the distance between host plant and sandalwood is $30 \mathrm{~cm}$ and $40 \mathrm{~cm}$ in the field (Subangshe, 2014). This research referred to previous studies that used a spacing of $40 \mathrm{~cm}$.

\section{Cajuput (M. cajuputi) Seed Preparation}

Cajuput seeds were propagated generatively by seeds. The seeds used were from Madiun. The procurement of cajuput seeds was the one harvested in May 2018. The initial preparation for conducting cajuput seedlings was begun with the preparation of a sow tub in the form of a medium-sized plastic tub with drainage underneath. After that, it was found that the cajuput seeds were small and very soft. The sowing was mixed with fine sand that was not blown by the wind (Kartikawati et al., 2014). The sow media was mixed with fine sand previously sterilized by roasting or it could be done by drying under the sun for 1-6 days.

\section{Citronella Grass (C. nardus) Preparation}

Citronella grass was propagated in vegetative manner by using saplings. The propagation of citronella seeds can also be obtained from the citronella flower itself, but the growth is less effective so they find difficulties to grow or in other words, the percentage of their life is small (Suroso, 2018). The source of the seeds came from Balitro and they were propagated by separating 1 sapling from the group. Then, it was planted in $25 \times 30 \mathrm{~cm}$ polybags which had been filled with media. The planting media used in this research were sand, topsoil and manure with a ratio of $4: 3: 3$. The next step was pruning the young shoots that had grown 1 month before being planted in the field. Observations were made by removing several plants in each treatment in order to determine the haustorium with the main plant at the end of the observation, that was 4 months after planting (BST) in each treatment including C, CKP, CSW CKPSW (Sandalwood, Citronella Grass and Cajuput).

\section{Field Observation}

Sandalwoods were planted with cajuput and citronella grass in the field. Measurements were taken at 1-4 months after planting. The parameters observed is presented in Table 1.

\section{Experimental Design and Data Analysis}

This research used a completely randomized design (CRD) with 4 treatments and 3 replications. The treatments were C and CKP, CSW and CKPSW (Table 1 ). The number of sandalwood seeds used was 72 , the number of cajuput seeds was 36 and the number of citronella saplings was 36. Equation of Completely Randomized Design (CRD) model with 4 treatments and 3 replications is presented below.

Where:

$$
Y \mathbf{i j}=\boldsymbol{\mu}+\tau_{\mathbf{i}}+\boldsymbol{E}_{\mathrm{i}} \mathbf{j}
$$

$\mathbf{Y}_{\mathrm{ij}}$ : Observations value on $-\mathrm{i}$ sandalwood and $-\mathrm{j}$ replication

ii : Sandalwood without host plant (C), sandalwood and cajuput host plant (CKP), sandalwood and citronella host plant (CSW), and mixed of sandalwood, cajuput and citronella plants (CKPSW)

jj $\quad: \quad 1^{\text {st }}, 2^{\text {nd }}, 3^{\text {rd }}$ replication

$\boldsymbol{\mu}:$ General mean value

$\boldsymbol{\tau}_{\mathrm{i}}$ : Effects of $-\mathrm{i}$ treatment of sandalwood

$\boldsymbol{\varepsilon}_{\mathbf{j}} \mathbf{j}$ : Random effects on sandalwood -i treatment and $-\mathrm{j}$ replication

Data analysis used analysis of variance at a $95 \%$ confidence level according to the CRD model (Matjik and Sumertajaya, 2006). Further tests using Duncan Multiple Range Test (DMRT) at a level of 5\% was carried out if the results of the analysis of variance showed that the treatment had a significant effect.

\section{RESULT AND DISCUSSION}

\section{Condition of Growing Site and Planting in the Field}

Based on the climate classification of Schmidt and Ferguson (1951), research location is in climate type of $\mathrm{D}$ and $\mathrm{E}$, and sandalwood grows naturally in dry land conditions in NTT. According to Surata (2004), optimal conditions for sandalwood growth are at an altitude of 600-1000 $\mathrm{m}$ above sea level with average rainfall of 600$1600 \mathrm{~mm} /$ year, average temperature of between 10-35oC during day time. Considering the climatic and topographical conditions in the research area which were 
considered suitable, the sandalwood growth opportunities were expected to be optimal.

In this research, there were 2 types of hosts, which are secondary hosts (medium-term hosts using citronella and long-term hosts using cajuput). The sandalwood host will function optimally if there is contact with the sandalwood root (haustorium). The artificial shade was used in the field when the plants were still young. This aimed to reduce excessive temperatures caused by high temperatures during the research. The maximum temperature during the research was 29.4-33.1 oC.

\section{Growth of Sandalwood and Host Plants}

The percentage of life of sandalwood seedlings for 4 months after they were planted with the host treatment of cajuput and citronella provided a significant effect on the growth of sandalwood. The results of the analysis of variance showed that the treatment provided a significant effect on all parameters from month 1 to month 4 after planting. The treatment of cajuput, citronella and the mixed of cajuput and citronella provided a significant effect on the growth of sandalwood seedling height, stem diameter and number of leaves. It indicated that the use of cajuput and citronella grass as host plants can increase the growth of sandalwood. The results of the analysis of the various effects of host plants on the growth of sandalwood are presented in Table 2.

\section{Sandalwood Plant Height}

The treatment of mixed host plants at the research location provided a significant effect on the growth parameters of sandalwood plant height. It can be seen in the results of Duncan's Test (Figure 2a) which shows that the highest growth was found in the treatment (CKPSW) (sandalwood-eucalyptus-citronella) because sandalwood obtained nutrients from the both host plants.

All treatments provided significant effects on the parameters of growth in height, stem diameter and number of leaves for several months after planting (MAP). The following is a graph of the results of the growth of the four parameters from the given treatment.

Table 1 Parameters observed in the field

\begin{tabular}{|c|c|}
\hline Treatment & Observation Parameters \\
\hline 1. Sandalwood $(\mathrm{C})$, & Seed height measurement $(\mathrm{T})$, \\
\hline 2. Sandalwood- cajuput (CKP), & Seed diameter $(\mathrm{D})$ \\
\hline 3. Sandalwood -citronella grass (CSW), & Leaves calculation $(\mathrm{J})$, \\
\hline 4. Sandalwood - cajuput citronella grass (CKPSW) & $\begin{array}{l}\text { Haustorium observation }(\mathrm{H}) \text {, } \\
\text { Number of citronella grass saplings (A) }\end{array}$ \\
\hline
\end{tabular}

Table 2 Recapitulation of analysis results of various effects of host plants on the growth of sandalwood (S. album) for several months after planting (MAP)

\begin{tabular}{|c|c|c|}
\hline Variable & \multirow{2}{*}{ P-value } & \multirow{2}{*}{ Host Plant } \\
\hline Growth in height $(\mathrm{cm})$ & & \\
\hline MAP1 & 0.0047 & $* *$ \\
\hline MAP2 & 0.0125 & $*$ \\
\hline MAP3 & 0.0035 & $* *$ \\
\hline MAP4 & 0.0001 & $* *$ \\
\hline \multicolumn{3}{|l|}{ Growth in stem diameter increase ( $\mathrm{mm}$ ) } \\
\hline MAP1 & 0.0001 & $* *$ \\
\hline MAP2 & 0.0001 & $* *$ \\
\hline MAP3 & 0.0004 & $* *$ \\
\hline MAP4 & 0.0001 & $* *$ \\
\hline \multicolumn{3}{|l|}{ Number of leaves } \\
\hline MAP1 & 0.0013 & $* *$ \\
\hline MAP2 & 0.0227 & $*$ \\
\hline MAP3 & 0.0004 & $* *$ \\
\hline MAP4 & 0.0001 & $* *$ \\
\hline
\end{tabular}

$* *$ Very significant $=\mathrm{P}$-value $<\alpha(0.01),{ }^{*}$ significant $=\alpha(0.01)<\mathrm{P}$-value $<\alpha(0.05),{ }^{\mathrm{tn}}$ insignificant $=P$-value $\geq \alpha(0.05)$. 


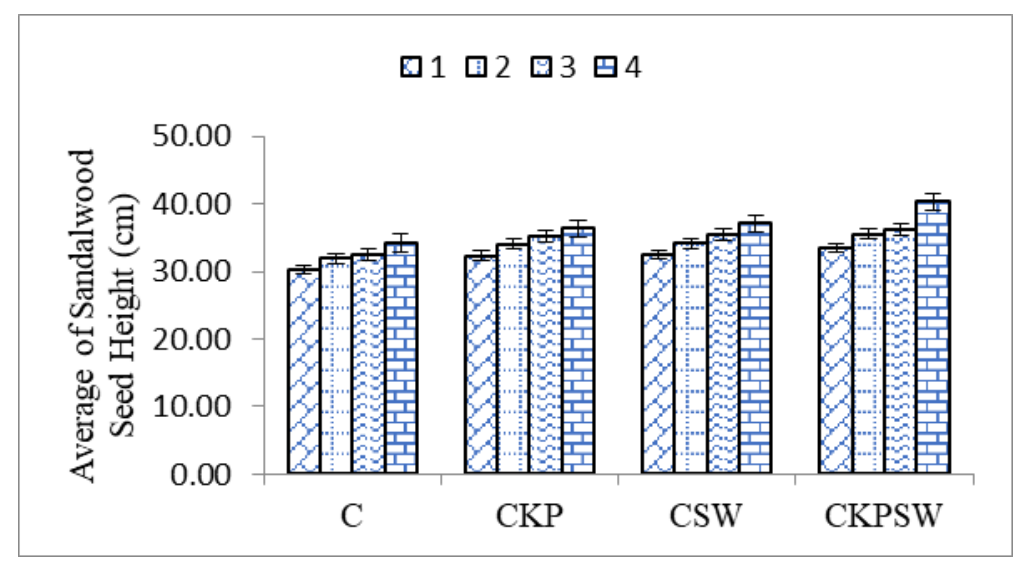

(a)

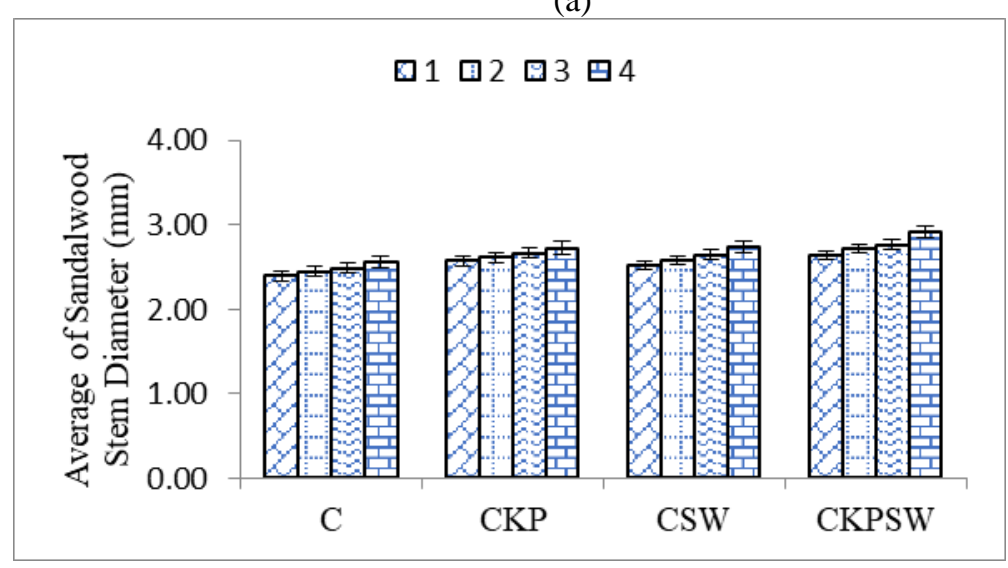

(b)

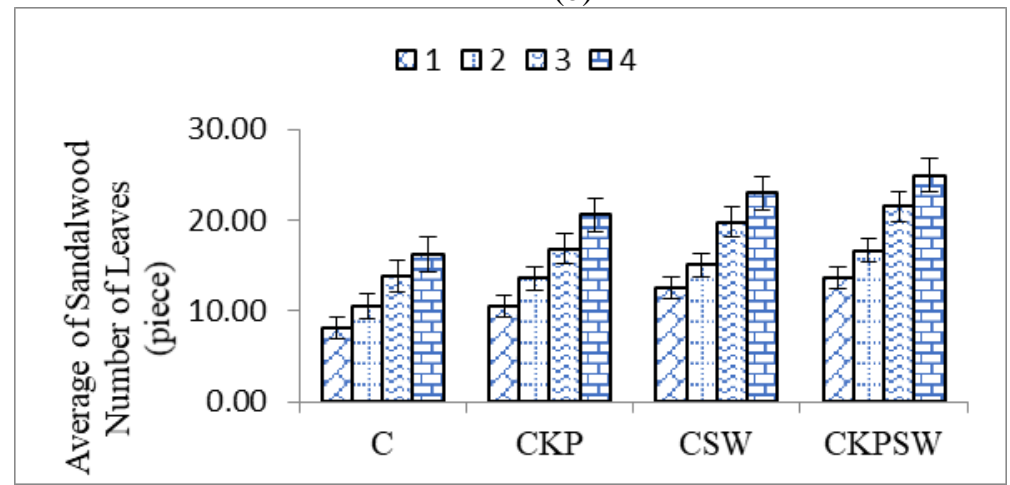

(c)

Note : without host plant (C), sandalwood and cajuput host plant (CKP), sandalwood and citronella host plant (CSW), mixed of sandalwood, cajuput and citronella plants (CKPSW)

Figure 2 Average of growth in seed height (a), stem diameter (b), number of leaves (c) on 4 treatments for 4 Months After Planting (MAP).

\section{Sandalwood Stem Diameter}

Stem diameter as plant dimension was used as plant growth parameter. The best treatment at the research location that showed the highest increase in stem diameter was CKPSW treatment. This treatment provided an increase in stem diameter reaching $14.06 \%$ since the beginning of planting at the age of 1-4 months after planting (MAP) (Figure 2b). The process of the diameter growth of sandalwood seeds occurs slowly, and this process occurs because cambium cell division towards the side (Pareira et al., 2018). It indicates that cajuput and citronella host plants can increase the growth of sandalwood in the diameter growth variable.

The CKPSW treatment provided the highest height and diameter compared to other treatments because the two types of plants were able to increase the growth of sandalwood in a mixed cropping pattern. Mixed cropping pattern allows for intensive cultivation development. It has many advantages for both types of plants. The advantages are the preservation of sandalwood plants from weed disturbances, faster growth of staple crops 
and increasing community income with a mixed cropping pattern.

\section{Number of Sandalwood Leaves}

Mixed host plant treatments showed an increase in the number of sandalwood leaves in the field at 4 MAP (months after planting). The best treatment was CKPSW (host plant mixture of sandalwood, cajuput and citronella). This treatment provided an increase in the number of leaves by $53.19 \%$ at 4 months after planting (MAP) (Figure 2c).

\section{Sandalwood Haustorium Observation}

The observations were made at the end of the research by removing several plants in each treatment in order to determine the amount of haustorium that had been formed for 4 months after planting (MAP) in the treatments such as C, CKP, CSW and CKPSW (Table 3). Sandalwood seeds have hemiparasitic properties, so their lives depend on other plants. This is indicated by the formation of haustorium. According to Surata (2012) the function of the haustorium itself can also be as an absorber for nutrients found in host plants.

According to Wawo (2008), with the entry of haustorium into the root vascular tissue, there will be a flow of water and nutrients from the roots of the host plant to the sandalwood roots and therefore, parasitism process occurs. Sandalwood roots and the roots of the host plant can be seen from the connection points of sandalwood roots (Pareira et al., 2018). The results of Duncan's test on the observation of the number of sandalwood haustoriums are presented in Table 5. It was found that the haustorium in sandalwood plants have been formed at the treatment site. The highest number of haustorium was found in the CKPSW treatment reaching 6, compared to the CSW, CKP, and C treatment.

\section{Growth of Cajuput Plant}

The increase in diameter is the secondary growth in plants. Secondary growth is initiated by the cambium which is present in the vascular tissue. The height growth of ajuput seedlings planted in the field at 4 months after planting showed that the highest growth was indicated by CKPSW treatment $(68.10 \mathrm{~cm})$ compared to the CKP treatment $(66.22 \mathrm{~cm})$. The growth of cajuput diameter on CKPSW (sandalwood-cajuput-citronella) mixed cropping showed an increase in diameter reaching of $5.64 \mathrm{~mm}$ (Table 4).

\section{Growth of Citronella Grass Saplings}

Observations on the increase in height, number of saplings and stem diameter were carried out for 4 months (1 once a month). The growth of citronella saplings planted side by side with sandalwood seedlings in the field was all good. The highest increase in height of citronella was shown in the CKPSW treatment which reached $60.00 \mathrm{~cm}$ compared to the sandalwood treatment and citronella (CSW) which showed a height of 56.58 $\mathrm{cm}$. The growth of plant height, stem diameter and number of saplings in a cluster is caused by the higher availability of nutrients from fertilization as a source of inorganic nutrients that assist in accelerating various metabolic processes (Setiawan et al., 2018). The average growth of citronella is presented in Table 5.

The increase in the growth of citronella grass was shown in the CKPSW and CSW treatments. The height growth of citronella was very significant as shown in the CKPSW treatment compared to the CSW treatment. It indicated that each citronella grass planted side by side with sandalwood was proven to be able to increase the growth of sandalwood seedlings in the field.

Table 3 Average increase in haustorium in all treatments in the field at 4 months after planting (MAP)

\begin{tabular}{llccc}
\hline \multirow{2}{*}{ Control } & \multicolumn{3}{c}{ Host Plants } \\
\cline { 2 - 4 } & Citronella Grass & Cajuput & Citronella Grass and Cajuput \\
\hline $0.33 \mathrm{c}$ & $5.66 \mathrm{a}$ & $2.66 \mathrm{~b}$ & $6.33 \mathrm{a}$ & \\
\hline
\end{tabular}

The numbers followed by the same letter show no significant difference at the level $\alpha 5 \%$.

Table 4 Average growth of cajuput (M. cajuputi)

\begin{tabular}{llll}
\hline Treatment & MAP & Height $(\mathrm{cm})$ & Diameter $(\mathrm{mm})$ \\
\hline \multirow{3}{*}{ CKP } & 1 & $46.44 \pm 1.079$ & $2.66 \pm 0.062$ \\
& 2 & $50.61 \pm 2.881$ & $3.16 \pm 0.061$ \\
& 3 & $57.17 \pm 3.166$ & $4.30 \pm 0.057$ \\
& 4 & $66.22 \pm 2.549$ & $5.63 \pm 0.062$ \\
\multirow{3}{*}{ CKPSW } & 1 & $48.21 \pm 0.922$ & $2.60 \pm 0.070$ \\
& 2 & $52.04 \pm 2.682$ & $3.18 \pm 0.118$ \\
& 3 & $60.17 \pm 3.015$ & $4.32 \pm 0.118$ \\
& 4 & $68.10 \pm 2.777$ & $5.64 \pm 0.049$ \\
\hline
\end{tabular}


Table 5 Average growth of citronella grass (C. nardus)

\begin{tabular}{lllll}
\hline Treatment & MAP & Height $(\mathrm{cm})$ & Diameter $(\mathrm{mm})$ & Number of Saplings \\
\hline \multirow{3}{*}{ CSW } & 1 & $48.48 \pm 2.803$ & $5.20 \pm 0.146$ & $2 \pm 1.211$ \\
& 2 & $50.54 \pm 4.20$ & $6.40 \pm 0.073$ & $4 \pm 0.963$ \\
& 3 & $50.56 \pm 5.693$ & $8.03 \pm 0.134$ & $7 \pm 1.464$ \\
& 4 & $56.58 \pm 5.028$ & $9.00 \pm 0.366$ & $9 \pm 0.857$ \\
\hline \multirow{2}{*}{ CKPSW } & 1 & $48.00 \pm 1.162$ & $5.40 \pm 0.070$ & $2 \pm 0.575$ \\
& 2 & $56.00 \pm 3.085$ & $7.60 \pm 0.070$ & $5 \pm 0.575$ \\
& 3 & $58.00 \pm 1.768$ & $8.20 \pm 0.135$ & $8 \pm 0.848$ \\
\hline
\end{tabular}

\section{CONCLUSION}

In studying the growth of sandalwood plants with citronella grass and cajuput as its host plants, it is proven that they provide significant effects in increasing the growth of sandalwood.

\section{REFERENCES}

Balai Penelitian Kehutanan (Balitbang) Kupang. 2009. Perkembangan Penelitian Dan Pengembangan Cendana di Nusa Tenggara Timur. Kupang: Badan Penelitian dan Pengembangan Kehutanan dan Konservasi Alam.

Banoet H. 2001 Peranan cendana dalam perekonomian NTT. Dulu dan kini. Berita Biologi. 5(5): 469474.

Dinas Kehutanan Provinsi NTT. 2009. Progres pengembangan hutan tanaman cendana Provinsi Nusa Tenggara Timur dalam rangka mewujudkan tekad Provinsi cendana: Kondisi Bulan Juni 2009. 97p. Kupang: Dinas Kehutanan Provinsi NTT.

Fitriani ER, Wirosoedarmo R, Rahadi BJ, Mustofa A. 2013. Pengaruh aplikasi sludge dari biodigester berbahan kotoran sapi di lahan kering terhadap pertumbuhan vegetatif tanaman jagung (Zea mays L.). Jurnal Sumberdaya Alam dan Lingkungan. 1(1): 26-30.

Haryjanto L. 2007. Konservasi Sumber Daya Genetik Cendana ( $\underline{\text { S. album }}$ L.). Prosiding Gelar Teknologi Cendana "Cendana untuk Rakyat: Pengembangan Tanaman Cendana di Lahan Masyarakat", tanggal 19 Desember 2006 Puslitbang Hutan dan Konservasi Alam. Bogor. 53-59.

IUCN 2007. The IUCN Red List Of Treated Species. IUCN, Gland, Switzerland.

Kartikawati KN, Rimbawanto A, Susanto M, Baskorowati, Prastyono 2014. Budidaya dan Prospek Pengembangan Kayu Putih (Melaleuca Cajuputi). Bogor: IPB Press.

Kementerian Kehutanan (Kemenhut) dan Pemerintah Provinsi NTT. 2010. Masterplan Pengembangan dan Pelestarian Cendana Provinsi Nusa Tenggara Timur Tahun 2010-2030. Kupang: Balai Penelitian Kehutanan Kupang.

Matjik AA, Sumertajaya IM. 2006. Perancangan Percobaan dengan Aplikasi SAS dan Minitab. Bogor: IPB Press.

Pareira MS, Mansur I, Dewi W. 2018. Pemanfaatan FMA dan tanaman inang atsiri untuk meningkatkan pertumbuhan bibit cendana $(\underline{S}$. album Linn). Jurnal Silvikultur Tropika. 9(3): 151-159.

Putri AI, Herawan T. 2008. Pengaruh Giberellin (GA4) terhadap waktu perkecambahan dan pertumbuhan tinggi semai cendana ( $\underline{S \text {. album }}$ Linn). J Ilmu Kehut. 2(2): 63-69.

Rahayu S, Wawo AH, Noordwijk MV, Hairiah K. 2002.

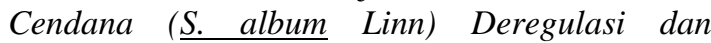
Pengembangannya. Bogor: World Agroforestry Center - ICRAF.

Schmidt FH, Ferguson JHA. 1951. Rainfall types based on wet and dry period ratio for Indonesia with western new Guinea. Jakarta: Jawatan Meteorologi dan Geofisika.

Setiawan NFN, Gusmaini NFN, Nurhayati H. 2018. The Response of citronella grass on several NPKMg fertlization levels in Latosol soil type. Buletin Penelitian Tanaman Rempah dan Obat. 29(2): 6978.

Subangshe SMCUP. 2014. Restoration of S. album L. resource in Sri Lanka: Distribution, seed storage, germination and establishment. Journal of the Department of Wildlife Conservation. 2014(2):155-164.

Surata IK. 2004. Teknik Budidaya Cendana. Aisuli. No 18 ISNN: $1410-1009$.

Surata IK. 2012. Pertumbuhan semai cendana ( $\underline{\text { S album }}$ Linn) pada beberapa ukuran kantung plastik di daerah semi arid. J Penelitian Kehut Wallacea. $1(1): 13-25$.

Suroso SP. 2018. Budidaya Serai Wangi (Cymbopogon nardus L. Randle). Penyuluh Kehutanan Lapangan Dinas Kehutanan dan Perkebunan, Daerah Istimewa Yogyakarta. 
Wawo AH. 2008. Studi perkecambahan biji dan pola

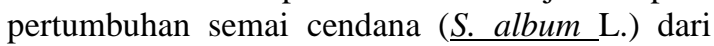
beberapa pohon induk di Kabupaten Belu, NTT. $J$ Biodiversitas. 9(2):117-122.

Wawo AH. 2009. Pengaruh jumlah semai Acacia villosa dan Leucaena glauca sebagai inang primer cendana. Balitro. 20(1): 50-58.
Weber HC. 1990. A new terminologi for parasitic plants. Haustorium 23:2.

Widiyanto A, Siarudin M. 2014. Sifat fisikokimia minyak kayu putih jenis Asteromyrtus brasii. J. Penelitian Hasil Hutan. 32(4) :243-252. 